\title{
Ethanol Production and Chlorophyll Fluorescence Predict Breakdown of Heat-stressed Apple Fruit During Cold Storage
}

\author{
Lihua Fan, Jun Song, Charles F. Forney, and Michael A. Jordan \\ Agriculture and Agri-Food Canada, Atlantic Food and Horticulture Research Centre, 32 Main Street, \\ Kentville, N.S., B4N 1J5, Canada
}

\begin{abstract}
Additional INDEX words. Malus sylvestris var. domestica, ethylene, flesh browning, heat injury, fruit quality
Abstract. Ethanol concentration and chlorophyll fluorescence (CF) were measured as signs of heat stress in apple fruit [Malus sylvestris (L.) Mill. var. domestica (Borkh.) Mansf.]. 'McIntosh', 'Cortland', 'Jonagold', and 'Northern Spy' apples were placed in trays and exposed to $46^{\circ} \mathrm{C}$ for $0,4,8$, or 12 hours. Following treatments, fruit were stored in air at $0{ }^{\circ} \mathrm{C}$ and evaluated after $\mathrm{0}, 1,2$, or 3 months. Ethanol and ethylene production, $\mathrm{CF}$, peel and flesh browning, firmness, skin color, soluble solids, and titratable acidity were measured. Increases in ethanol were apparent immediately following 12-hour heat treatments as well as after 3 months. After 3 months, ethanol concentrations were 16-, 52-, 6-, and 60-fold higher in 'McIntosh', 'Cortland', 'Jonagold', and 'Northern Spy' apples than in controls, respectively. The concentrations of ethanol accumulated reflected the degree of heat-induced fruit injury. Heat treatments reduced ethylene production relative to control values. After 3 months of storage ethylene production of fruit exposed to $46{ }^{\circ} \mathrm{C}$ for $12 \mathrm{~h}$ was $<0.48 \mu \mathrm{mol} \cdot \mathrm{kg}^{-1} \cdot \mathrm{h}^{-1}$ compared to $>4.3 \mu \mathrm{mol} \cdot \mathrm{kg}^{-1} \cdot \mathrm{h}^{-1}$ for controls. Heat treatments also reduced $\mathrm{CF}$ which was expressed as $\mathrm{Fv} / \mathrm{Fm}$, where $\mathrm{Fv}$ is the difference between the maximal and the minimal fluorescence $(\mathrm{Fm}-\mathrm{Fo})$, and $\mathrm{Fm}$ is the maximal fluorescence. After 3 months storage at $0{ }^{\circ} \mathrm{C}, \mathrm{Fv} / \mathrm{Fm}$ was $\approx 0.2$ in fruit held at $46{ }^{\circ} \mathrm{C}$ for 12 hours compared with 0.5-0.6 for control fruit. Exposure to $46^{\circ} \mathrm{C}$ for 12 hours caused severe peel and flesh browning in all cultivars. Severity of peel and flesh browning increased with increasing duration of heat treatment and subsequent storage at $0{ }^{\circ} \mathrm{C}$. 'Northern Spy' apple fruit were most susceptible to heat stress based on the degree of flesh browning. Heat treatments of 8 and 12 hours reduced firmness of 'McIntosh', 'Cortland', and 'Northern Spy', but not 'Jonagold' apples. Hue angle of the green side of fruit was also reduced in 'Cortland', Jonagold' and 'Northern Spy' apples receiving the 8- and 12-hour treatments. Heat treatments caused a decrease in fruit tiratable acidity, but had no effect on soluble solids content. The increase in ethanol production and decrease in CF correlated with heat-induced injury, and were apparent before browning was visually apparent. Ethanol and CF have the potential to be used to nondestructively predict the severity of injury that develops during storage.
\end{abstract}

The quality and storage life of apple fruit are affected by various pre- and post harvest factors. Heat stress is one factor that can cause physiological damage to apple fruit resulting in shorter storage life and reduced quality. Heat treatments have been used to alter physiological and biochemical characteristics of apple fruit in order to improve quality retention and storage life (Lurie, 1998; Porritt and Lidster, 1978). However, high temperatures with long durations may cause damage, expressed as skin discoloration and flesh browning (Klein and Lurie, 1992; Song et al., 2001). In mild-to-moderate heat injury, visual symptoms are often not apparent, however, flesh injury may develop during subsequent storage. Therefore, finding a time-temperature regime to reduce storage losses and maximize fruit quality is critical to maximize the benefits of heat treatments.

Factors that determine apple storage life include cultivar, fruit maturity, growing environment, cultural practices, postharvest handling, and storage conditions (Hardenburg et al., 1986, Prange et al., 1993). Predicting fruit storage life has been an ongoing challenge to maximize fruit value and minimize wastage. Bramlage et al. (1985) developed a model based on fruit mineral composition that successfully predicted storage life of 'McIntosh' apples

Received for publication 5 Apr. 2004. Accepted for publication 10 Aug. 2004 Contribution 2281 of the Atlantic Food \& Horticulture Research Centre, Agriculture \& Agri-Food Canada. We thank the Nova Scotia Fruit Grower Associates for their financial support. We thank Kumudini U.K.G. Nicholas for technical assistance in the evaluation of fruit quality and Drs. Robert Prange and John DeLong for their helpful suggestions in preparing the manuscript.
$69 \%$ of the time, but the model failed to predict breakdown in seasons when fruit were subjected to greater amounts of stress. More reliable methods are still needed to identify detrimental effects of heat and other stresses in apple fruit and determine their effects on storage life.

Plants produce many different volatile compounds that reflect their physiological state and may indicate stress (Charron et al., 1995; Woodstock and Taylorson, 1981). Volatile compounds, such as ethanol, ethyl acetate, acetaldehyde, and ethylene, have been reported to indicate plant injury from water stress, freezing, and heat stress (Forney and Jordan, 1998; Forney et al., 2000; Kimmerer and Kozlowski, 1982; Song et al., 2001). In 'McIntosh', 'Cortland', and 'Northern Spy' apple fruit, ethanol production increases substantially $1 \mathrm{~d}$ after exposure to $46^{\circ} \mathrm{C}$ for 8 or $12 \mathrm{~h}$ and the increase of ethanol was correlated with fruit injury (Song et al., 2001).

Chlorophyll fluorescence (CF) was suggested as an early indicator of heat stress in fruit (Smillie, 1992) and has been used as an indicator of postharvest freezing and heat stress in apple. Forney et al. (2000) characterized freezing induced changes of 'Northern Spy' and 'Delicious' apples using CF. Chlorophyll fluorescence $(\mathrm{Fv} / \mathrm{Fm})$ decreases rapidly $1 \mathrm{~d}$ following a 12 -h heat treatment at $46^{\circ} \mathrm{C}$ in 'McIntosh', 'Cortland', 'Jonagold', and 'Northern Spy' apple fruit and changes in $\mathrm{CF}$ of fruit could serve as an indicator of heat stress (Song et al., 2001). However, the value of volatile emissions and CF to predict fruit quality in heat-stressed apples during storage has not been reported. Therefore, the objectives of this study were to investigate the physiological changes in heat- 
stressed apple fruit during storage by characterizing emission of volatiles and changes in CF induced by heat stress and relating them to changes in fruit quality during storage.

\section{Materials and Methods}

Heat treatment. Apple fruit of 'McIntosh', 'Cortland', 'Jonagold', and 'Northern Spy' grown commercially in the Annapolis Valley, Nova Scotia, Canada, were obtained at harvest time from a packinghouse. Heat treatments of these fruit were conducted by placing fruit in a $46^{\circ} \mathrm{C}$ chamber with $85 \%$ to $90 \%$ relative humidity at 4 -h intervals. When all fruit were removed, the durations of heat treatments were $0,4,8$, and $12 \mathrm{~h}$. These treatment times were chosen to induce varying degrees of heat stress. The 0 -h fruit were used as the control. Temperature was monitored for each cultivar during the heat treatment by placing thermocouples in the cortex of selected apples following the procedures described by Song et al. (2001). After the heat treatments, fruit were stored at $0^{\circ} \mathrm{C}$ in air. Fruit were evaluated following $0,1,2$, or 3 months of storage after an additional $1 \mathrm{~d}$ at $20^{\circ} \mathrm{C}$.

VoLATILE ANALYSIS. Three subsamples of four apples each from each cultivar-heat treatment combination were sealed in 4-L glass jars with Teflon lids at $20^{\circ} \mathrm{C}$ to determine composition of volatiles. The headspace over the apples was allowed to equilibrate for 1 $\mathrm{h}$, following which $1 \mathrm{~mL}$ headspace samples were analyzed on a gas chromatograph (GC) (model 3400; Varian,Walnut Creek, Calif.) with a flame ionization detector and a SupelcoWax 10 column with $30 \mathrm{~m} \times 0.53 \mathrm{~mm}$ i.d., $1.0-\mu \mathrm{m}$ coating thickness (Supelco, Bellefonte, Pa.). The carrier gas was ultra-high purity helium (99.999\%; Praxair, Mississauga, Ont., Canada) at a flow rate of $9 \mathrm{~mL} \cdot \mathrm{min}^{-1}$. The GC parameters and analysis were performed as described by Song et al. (2001). Quantification was done by comparison of the GC response of the sample to that of standard compounds.

ETHYLENe PRODUCTION. One-milliliter samples of headspace from the same three subsamples of apples were taken and analyzed for ethylene. A gas chromatograph with a flame ionization detector (Carle Instuments, Anaheim, Calif.) equipped with a $1.9 \mathrm{~m} \times 3.2-\mathrm{mm}$ (o.d.) activated alumina column with a helium carrier flow of $50 \mathrm{~mL} \cdot \mathrm{min}^{-1}$ was used. Quantification was completed by comparison of the GC response of the sample to that of certified standards.

Chlorophyll Fluorescence. Chlorophyll fluorescence was determined using a modulated fluorometer (model OS-500; OptiScience, Tyngsboro, Mass.) on 10 apples from each cultivar-heat treatment combination. Fruit were at $20^{\circ} \mathrm{C}$ and were dark-adapted for a minimum of $30 \mathrm{~min}$ prior to $\mathrm{CF}$ measurement. The fluorometer was operated in the "Fv/Fm" mode, and fluorescence was measured using a photodiode in the 710-760-nm range. In a darkened laboratory, the fluorescence probe was placed firmly on the surface of apple fruit and a pulse of $10 \mathrm{mmol} \cdot \mathrm{m}^{-2 \cdot} \cdot \mathrm{s}^{-1}$ was applied for $0.8 \mathrm{~s}$. Fluorescence parameters of minimal fluorescence (Fo), maximal fluorescence (Fm), and photochemical efficiency $(\mathrm{Fv} / \mathrm{Fm}$, where $\mathrm{Fv}=\mathrm{Fm}-\mathrm{Fo})$ were recorded from the fluorometer digital display. Fv/Fm was used to express CF in this study and three readings from each fruit were read and averaged.

Fruit Quality. Samples of 10 apples of each cultivar-heat treatment combination were evaluated at each removal. External and internal fruit injury were rated as peel or flesh browning using a scale of $0-5$ where $0=$ none, $1=$ up to $20 \%, 2=21 \%$ to $40 \%$, $3=41 \%$ to $60 \%, 4=61 \%$ to $80 \%$, and $5=81 \%$ to $100 \%$ of the fruit surface or flesh area affected. To rate flesh browning, apples were cut in half equatorially. Fruit firmness was determined on both red and green sides of each fruit after peel removal using a Magness-Taylor (MT) firmness tester (type $30 \mathrm{lb}$, model 30A; Ballauf Manufacturing Co., Laurel, Md.). Surface color of 10 apple fruit was measured using a chromameter (model 200; Minolta Camera Co., Osaka, Japan) and L* (L value), C* (chroma), and $\mathrm{H}^{\circ}$ (hue angle) were recorded. Color readings were made on both red and green sides of each fruit. Hue angle was used to represent color change in this study. The juice collected from 10-apple fruit during firmness testing was analyzed for percent soluble solids content using a hand-held temperature-compensated refractometer (Atago Co., Tokyo). Titratable acidity was measured with a 2$\mathrm{mL}$ juice sample and $0.1 \mathrm{~mol} \cdot \mathrm{L}^{-1} \mathrm{NaOH}$ using a semi-automatic titrator (Multi-Dosimat E-415 titrator; Metrohm AG, Herisau, Switzerland) to a phenolphthalein endpoint of $\mathrm{pH}$ 8.1.

Statistical analysis. The experimental design was a completely randomized $4 \times 4 \times 4$ factorial, with four cultivars, four heat treatments, and four storage periods. For each combination, three subsamples of four apples were used for volatile analysis, while 10 fruit were used for fluorescence and quality measurement. Data were analyzed using analysis of variance, correlation coefficient, and LSD options of Genstat 5 (Genstat 5 Committee, 1993).

\section{Results}

Ethanol PROduction. Heat stress induced production of ethanol was a significant indicator of heat stress during storage (Fig. 1). Following a 4 -h exposure to $46^{\circ} \mathrm{C}$, ethanol production was not significantly greater than controls in 'McIntosh', 'Cortland', 'Jonagold', or 'Northern Spy' fruit at 0 months (1 d after heat treatment) and remained at its initial level after 3 months of storage at $0{ }^{\circ} \mathrm{C}$. However, ethanol concentration increased significantly at 0 months following the 8- and 12-h exposure to $46^{\circ} \mathrm{C}$ in 'McIntosh', 'Cortland', and 'Northern Spy'. During the storage period, headspace ethanol concentration remained elevated in the treated apple fruit in these three cultivars. When apples were exposed to $46{ }^{\circ} \mathrm{C}$ for $12 \mathrm{~h}$ and then stored for 3 months, ethanol concentrations were 16-, 52-, 6-, and 60-fold higher than the controls in 'McIntosh', 'Cortland', 'Jonagold', and 'Northern Spy', respectively.

Ethylene Production. At 0 months and $1 \mathrm{~d}$ following the 4-h exposure to $46^{\circ} \mathrm{C}$, ethylene production was inhibited in all cultivars except for 'Jonagold' (Fig. 2). However, during storage, ethylene production increased to levels similar or higher than that of the controls. After 3 months storage, ethylene production in fruit treated for $4 \mathrm{~h}$ at $46{ }^{\circ} \mathrm{C}$ was $205 \%, 82 \%, 164 \%$, and $92 \%$ of the control in 'McIntosh', 'Cortland', 'Jonagold', and 'Northern Spy', respectively. Following an 8- or 12 -h exposure to $46^{\circ} \mathrm{C}$, ethylene production of treated apples was significantly reduced in all four cultivars, and remained lower than controls during storage. Following 3 months storage, ethylene production in apples exposed to $46{ }^{\circ} \mathrm{C}$ for $12 \mathrm{~h}$ declined to $0.02,0.25,0.48$, and $0 \mu \mathrm{mol} \cdot \mathrm{kg}^{-1} \cdot \mathrm{h}^{-1}$ in 'McIntosh', 'Cortland', 'Jonagold', and 'Northern Spy', respectively.

Chlorophyll fluorescence (Fv/FM). In general, Fv/Fm declined gradually during storage in apple fruit exposed to 46 ${ }^{\circ} \mathrm{C}$ for 0 or $4 \mathrm{~h}$ (Fig. 3). The 4-h heat treatment had no significant effect on $\mathrm{Fv} / \mathrm{Fm}$ during the 3-month storage period in all four cultivars. However, Fv/Fm decreased significantly in all cultivars exposed to $46{ }^{\circ} \mathrm{C}$ for 8 or $12 \mathrm{~h}$. When apples were exposed to 46 ${ }^{\circ} \mathrm{C}$ for $12 \mathrm{~h}$, the decrease in Fv/Fm was greatest. After 3 months 


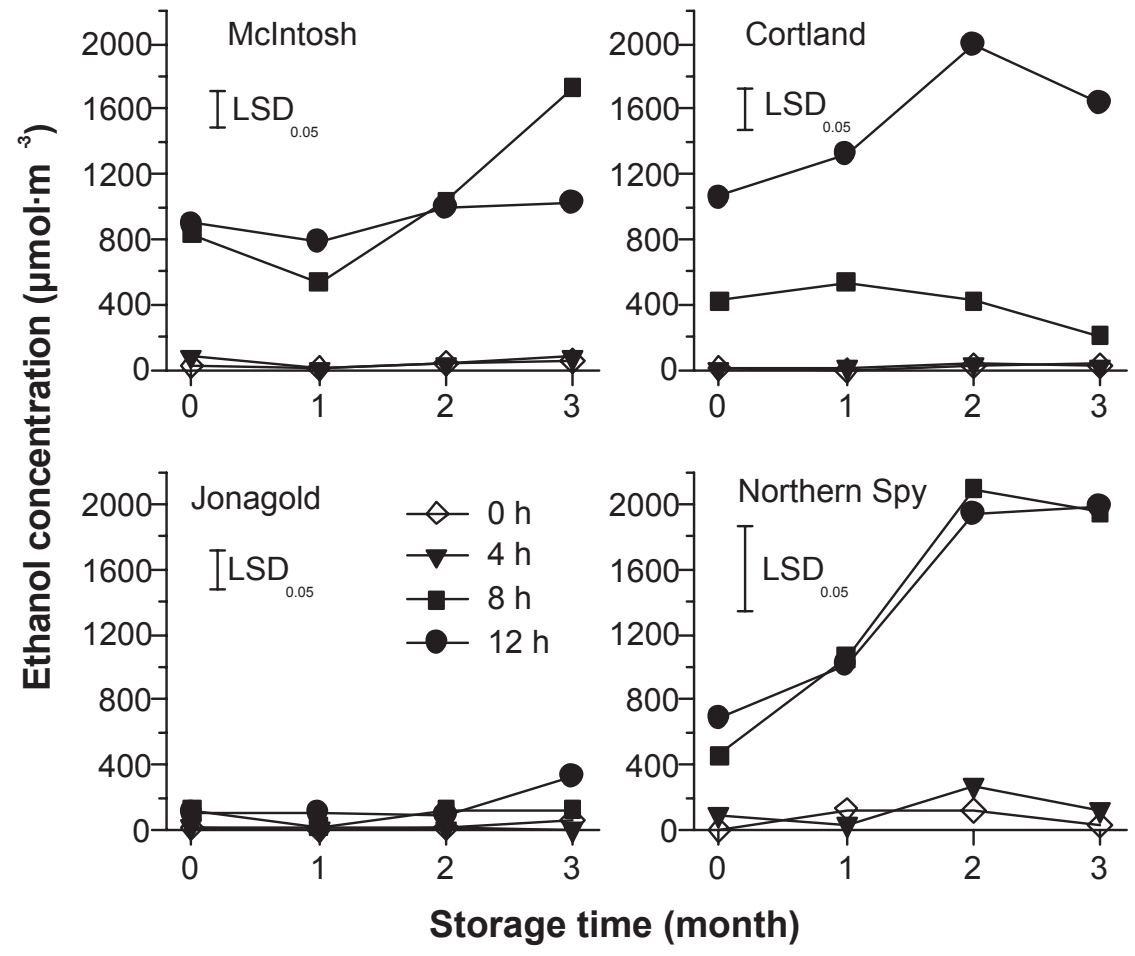

Fig. 1. Headspace ethanol concentration of 'McIntosh', 'Cortland', 'Jonagold', and 'Northern Spy' apples treated at $46{ }^{\circ} \mathrm{C}$ for $0,4,8$, or $12 \mathrm{~h}$ following $0,1,2$, or 3 months of storage at $0{ }^{\circ} \mathrm{C}$. The vertical bar represents the LSD at $P<0.05$ for comparison of means within the figure.

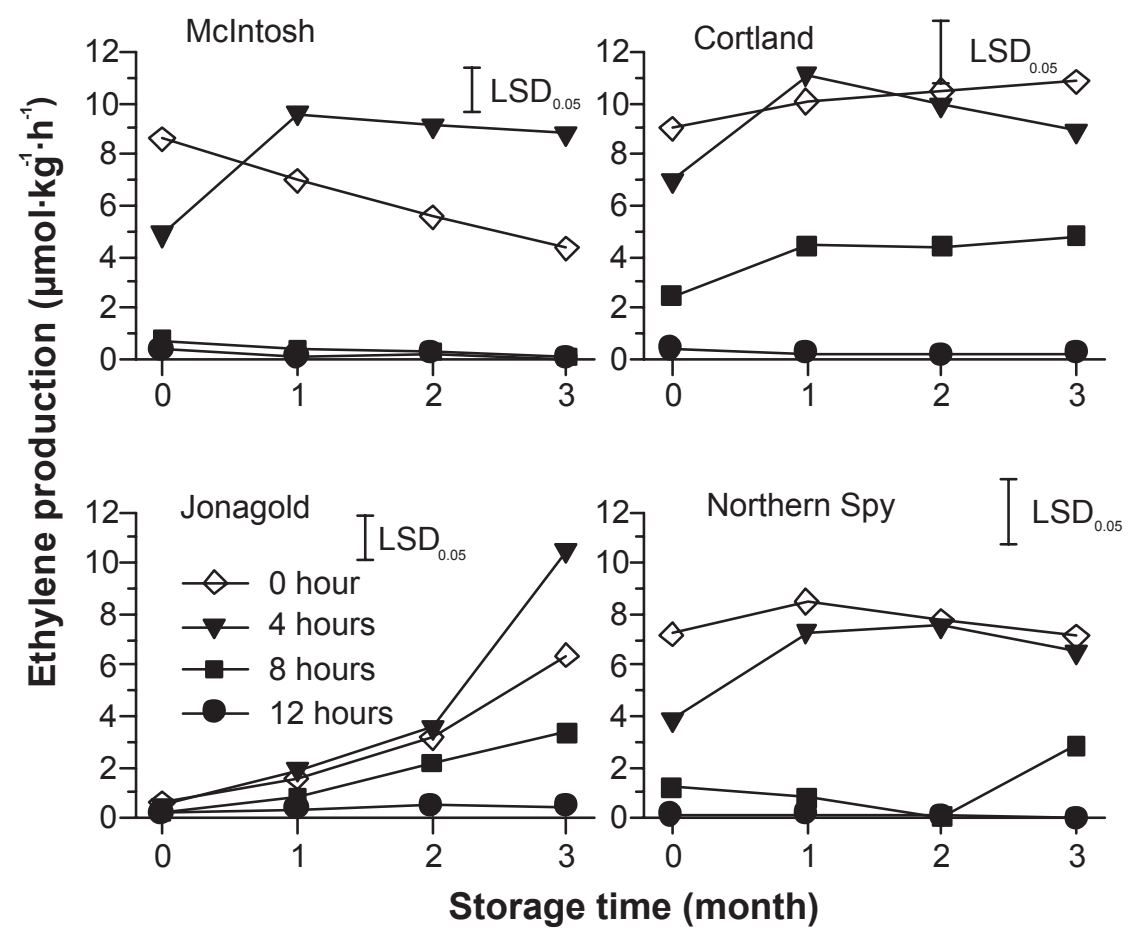

Fig. 2. Ethylene production of 'McIntosh', 'Cortland', 'Jonagold', and 'Northern Spy' apples treated at $46{ }^{\circ} \mathrm{C}$ for $0,4,8$, or $12 \mathrm{~h}$ following $0,1,2$, or 3 months of storage at $0{ }^{\circ} \mathrm{C}$. The vertical bar represents the LSD at $P<0.05$ for comparison of means within the figure. of storage, Fv/Fm of treated apples declined to $8 \%, 42 \%, 45 \%$, and $30 \%$ of the control values in 'McIntosh', 'Cortland', 'Jonagold', and 'Northern Spy', respectively. The results indicated that 'McIntosh' and 'Northern Spy' were most damaged by the 8- and 12-h heat stress.

Fruit injury. Following exposure to $46{ }^{\circ} \mathrm{C}$ for $4 \mathrm{~h}$, significant peel or flesh browning only occurred in 'Northern Spy' apples during the 3 -month storage period (Figs. 4 and 5). One day following the 8- or 12-h treatments (at 0 months), peel browning was only found in 'Northern Spy' apples while flesh browning was observed both in 'McIntosh' and 'Northern Spy' apples. In 'Cortland' apples, no significant peel or flesh browning occurred at 0 months $1 \mathrm{~d}$ following exposure to $46^{\circ} \mathrm{C}$ for 8 or $12 \mathrm{~h}$; however, peel and flesh browning was readily apparent after 1 month of storage, and increased further after 2 or 3 months of storage. During storage, severity of peel or flesh browning increased in apples exposed to $46^{\circ} \mathrm{C}$ for 8 or $12 \mathrm{~h}$ in all four cultivars. 'Jonagold' was most resistant to heat stress based on the peel and flesh browning ratings.

OTHER FRUIT QUALITY PARAMETERS. In addition to peel and flesh browning, fruit firmness, fruit skin color, soluble solids, and titratable acidity were measured to investigate additional effects of heat treatments on fruit quality. Following the 4-h heat treatment, fruit firmness remained the same as controls in all four cultivars after 3 months storage (Fig. 6). However, following the 8- or 12-h heat treatments, fruit firmness decreased significantly in 'McIntosh', 'Cortland', and 'Northern Spy' during storage, which coincided with higher flesh browning after $2-3$ months storage. Hue angle measured on the green side of the apple declined significantly during storage in 'Cortland', 'Jonagold', and 'Northern Spy' apples exposed at $46^{\circ} \mathrm{C}$ for 8 or $12 \mathrm{~h}$ (Fig. 7). Soluble solids were not affected by heat treatments (data not shown). Fruit titratable acidity declined sharply in all four apple cultivars following the 8- or 12-h heat treatment. After 3 months of storage, the titratable acidity in the 12-h heat-treated apples was 3.47, 1.11, 3.24 , and $4.04 \mathrm{mg} \cdot \mathrm{mL}^{-1}$ malic acid equivalents, which was equal to $74 \%, 25 \%, 79 \%$, and $72 \%$ of the control values in 'McIntosh', 'Cortland', 'Jonagold', and 'Northern Spy', respectively.

CORRELATIONS OF FLESH BROWNING WITH VOLATILES, CHLOROPHYLL FLUORESCENCE, AND FRUIT QUALITY. Flesh browning reflected the physiological injury caused by heat stress on the fruit. The severity of flesh browning during storage correlated most strongly and consistently with the increase in ethanol and decrease in $\mathrm{CF}$ induced by heat stress. During storage, flesh browning was highly correlated with ethanol concentration and negatively correlated with 


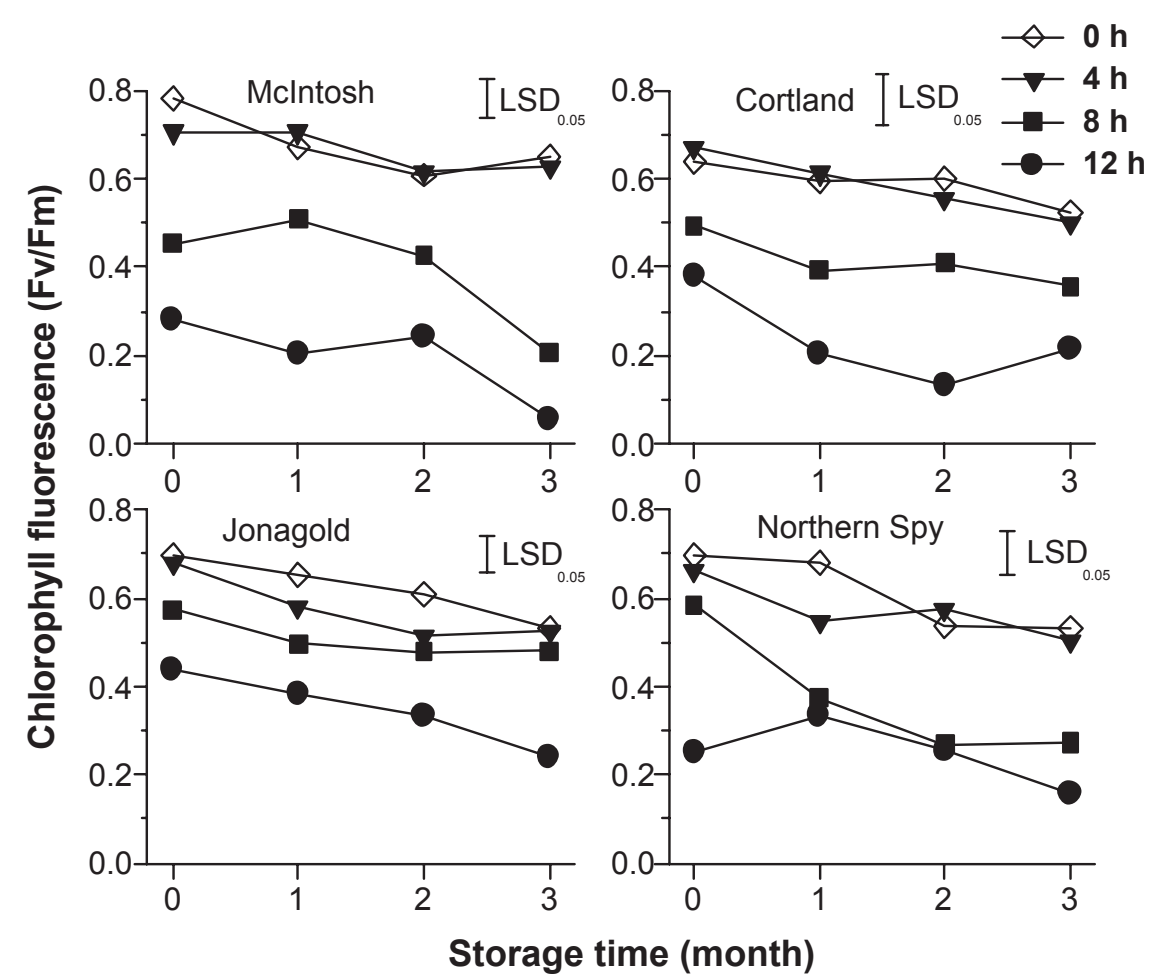

Fig. 3. Chlorophyll fluorescence (expressed as Fv/Fm where $\mathrm{Fo}=$ minimal fluorescence, $\mathrm{Fm}=$ maximal fluorescence and Fv = Fm - Fo) of 'McIntosh', 'Cortland', 'Jonagold', and 'Northern Spy' apples treated at $46^{\circ} \mathrm{C}$ for $0,4,8$, or $12 \mathrm{~h}$ following $0,1,2$, or 3 months of storage at $0{ }^{\circ} \mathrm{C}$. The vertical bar represents the LSD at $P<0.05$ for comparison of means within the figure.
Fv/Fm in 'McIntosh' $(r=0.86,-0.91)$, 'Cortland' $(r=0.87,-0.87)$,'Jonagold' $(r=0.78,-0.68)$, and 'Northern Spy' $(r=0.85,-0.83)$. Flesh browning also correlated well with ethylene production in 'McIntosh' ( $r=-0.81)$, 'Cortland' ( $r=-0.85$ ), and 'Northern Spy' $(r=-0.85)$, but not in 'Jonagold' ( $r=-0.41)$. Ethyl acetate was strongly correlated with flesh browning in 'Jonagold' $(r=0.87)$; however, correlations were weak in 'McIntosh' $(r=0.46)$, 'Cortland' $(r=0.50)$, and 'Northern Spy' ( $r=0.03$ ). Flesh browning was highly correlated with peel browning and negatively correlated with firmness.

To determine the value of ethanol and $\mathrm{CF}$ to predict the development of flesh browning in apple fruit during storage, values of ethanol and CF measured $1 \mathrm{~d}$ after heat treatments were plotted against flesh browning ratings of fruit throughout the 3-month storage period (Fig. 8). Ethanol concentration $>200 \mu \mathrm{mol} \cdot \mathrm{m}^{-3}$ appeared to be predictive of the development of flesh browning during storage. This threshold value was effective in predicting all flesh browning ratings $>1$ with the exception of 'Jonagold' fruit that were heat treated for 8 or $12 \mathrm{~h}$. Fv/Fm values $<0.6$ also were predictive of the development of flesh browning during storage. This threshold value was effective in predicting all flesh browning ratings $>1$.

\section{Discussion}

Many reports focus on the positive response of commodities to heat treatments, however, there is always a danger of these treatments causing tissue damage. Efforts to find a time-temperature regime that will produce desired positive effects without damaging fruits and vegetables has resulted in a multitude of recommended treatments (Lurie, 1998). Heat damage in fruit can be both external and internal. External damage generally appears as peel browning (Klein and Lurie 1992; Lay-Yee and Rose, 1994; Woolf and Laing, 1996), while internal damage is often expressed as flesh browning (Jacobi et al., 1993; Lay-Yee and Rose, 1994; Song et al., 2001). In apple fruit, flesh browning is a diffuse browning of the flesh that may affect the outer flesh, the tissue around the core, or both. In advanced stages, browning may encompass most of the internal tissue of the fruit (Meheriuk et al., 1994). In our study, heat injury usually was not visible in apples $1 \mathrm{~d}$ following heat treatments and no peel browning was observed on 'McIntosh', 'Cortland', or 'Jonagold' apples, while only slight amounts were seen on 'Northern Spy'. Similarly, $1 \mathrm{~d}$ following heat treatments, flesh browning (which was only visible when the fruit were cut) and loss of firmness were slight in 'Cortland' and 'Jonagold' while more apparent in 'McIntosh' and 'Northern Spy'. After 1 month of storage, peel browning became apparent and 


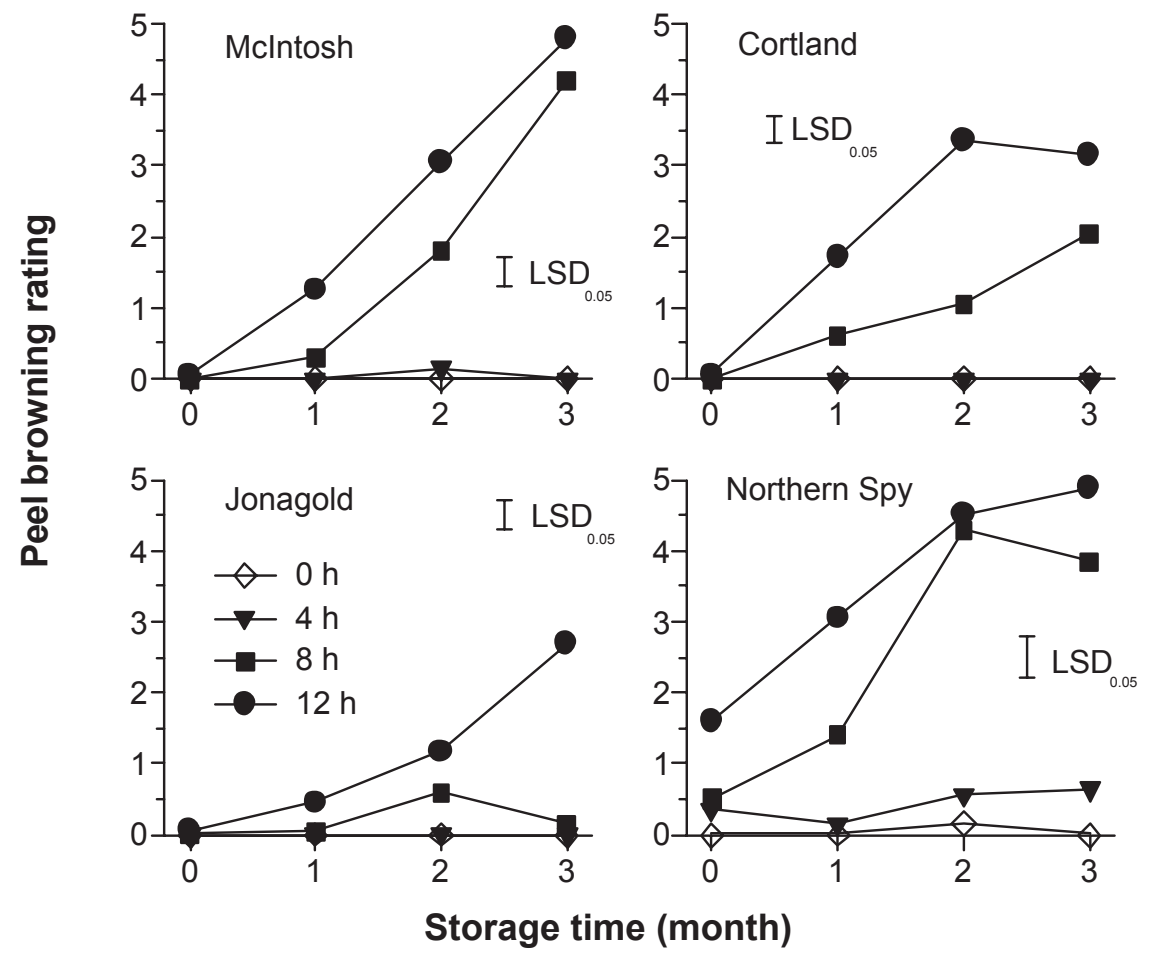

Fig. 5. Peel browning rating of 'McIntosh', 'Cortland', 'Jonagold', and 'Northern Spy' apples treated at $46{ }^{\circ} \mathrm{C}$ for $0,4,8$, or $12 \mathrm{~h}$ following $0,1,2$, or 3 months of storage at $0{ }^{\circ} \mathrm{C}$. Peel browning was rated on a scale of 0 to 5 , where $0=$ none, $1=$ up to $20 \%, 2=21 \%$ to $40 \%, 3=41 \%$ to $60 \%, 4=61 \%$ to $80 \%$, and $5=81 \%$ to $100 \%$ of the peel area affected. The vertical bar represents the LSD at $P<0.05$ for comparison of means within the figure.

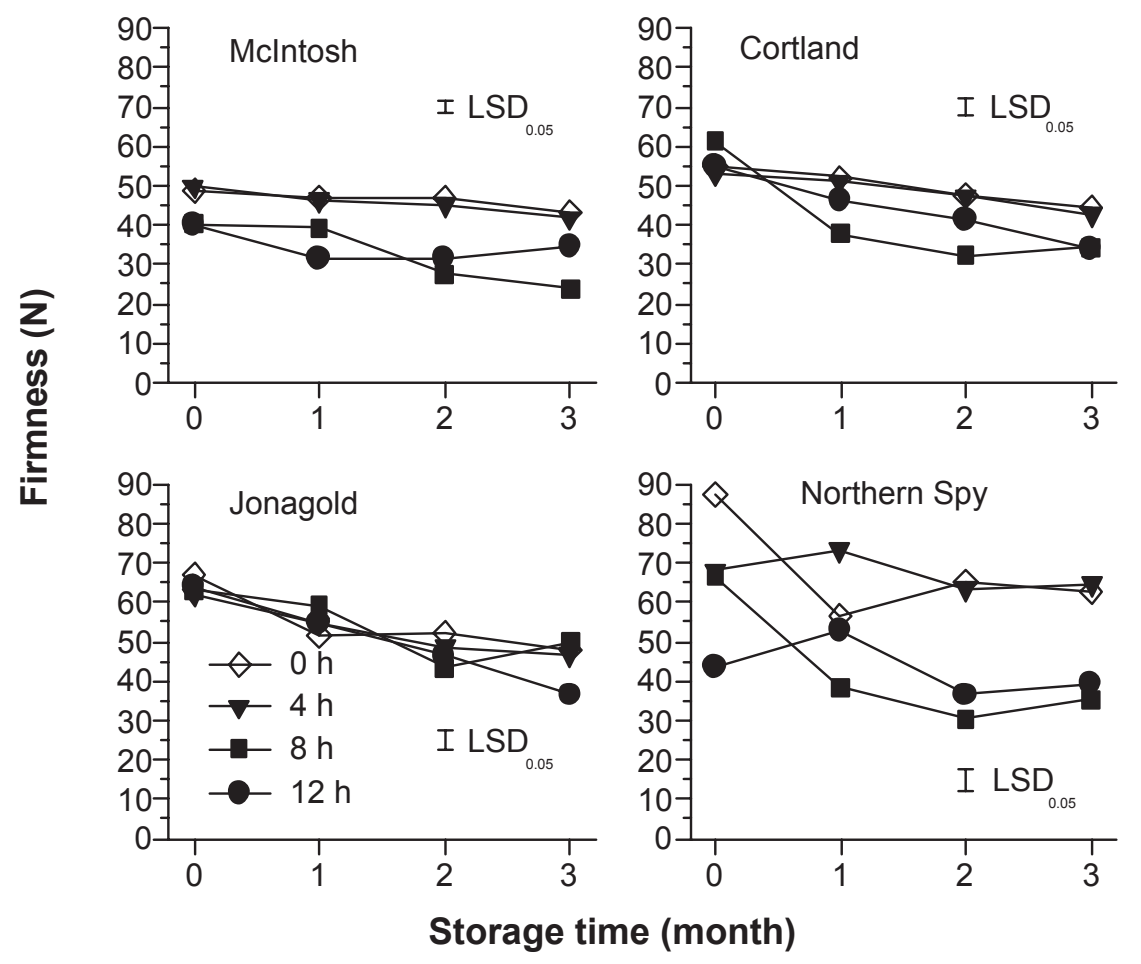

Fig. 6. Firmness of 'McIntosh', 'Cortland', 'Jonagold', and 'Northern Spy' apples treated at $46{ }^{\circ} \mathrm{C}$ for 0 , 4,8 , or $12 \mathrm{~h}$ following $0,1,2$, or 3 months of storage at $0^{\circ} \mathrm{C}$. The vertical bar represents the LSD at $P<$ 0.05 for comparison of means within the figure. flesh browning and loss of firmness became more severe in apples from the moderate and severe heat treatments, caused by exposure to $46^{\circ} \mathrm{C}$ for 8 or $12 \mathrm{~h}$. Severity of both peel and flesh browning continued to increase with storage time.

'McIntosh' and 'Cortland' are chillingsensitive cultivars and may develop low-temperature breakdown and flesh browning when stored at $0^{\circ} \mathrm{C}$ (Meheriuk et al., 1994). In this study, 'McIntosh' and 'Cortland' were stored at $0{ }^{\circ} \mathrm{C}$, but the control fruit did not develop low-temperature breakdown after 3 months of storage. Therefore, it would be assumed that the flesh browning observed in heat-treated fruit was caused by heat stress. However, the chilling stress of storage at $0{ }^{\circ} \mathrm{C}$ may have enhanced heat injury symptoms. Additional research would be required to characterize the effect of storage temperature on tissue breakdown of heat-stressed apples.

Volatile emissions are a good indicator of the physiological status of plant tissues. In our study, ethanol production was stimulated by heat stress, suggesting a substantial alteration of respiratory metabolism. Under mild heat stress, such as exposure of apples to $46^{\circ} \mathrm{C}$ for $4 \mathrm{~h}$, no ethanol was induced, indicating minimal physiological damage. However, moderate or severe heat stress immediately induced high concentrations of ethanol, which remained high throughout 3 months of storage. Ethanol production is usually associated with glycolysis and reduced $\mathrm{O}_{2}$ availability; reduced $\mathrm{O}_{2}$ is thought to inhibit mitochondrial electron transport leading ultimately to formation of ethanol. Under aerobic conditions, little or none of these glycolytic metabolites are normally produced (Davies, 1980). However, stress may disrupt normal electron transport and stimulate glycolysis. Ethanol has been reported to be produced by other plant tissues as a response to stress (Templeton and Colombo, 1995; Toivonen, 1997). Thomas (1931) reported that internal breakdown and soft scald in stored apples were associated with increases in ethanol and acetaldehyde in the fruit. In our study acetaldehyde and ethyl acetate also increased significantly in stressed fruit during storage (data not shown) further indicating induction of glycolytic metabolism.

Measurement of stress ethylene also can be a useful indicator of the degree of stress that a plant has experienced (Tingey et al., 1976). In our study ethylene production in fruit from the 4-h heat treatment was similar or higher than in control fruit during storage in all four cultivars. However, ethylene was inhibited $1 \mathrm{~d}$ following exposure to 46 ${ }^{\circ} \mathrm{C}$ for 8 or $12 \mathrm{~h}$, and remained consistently low during 3 months of storage. When stress 


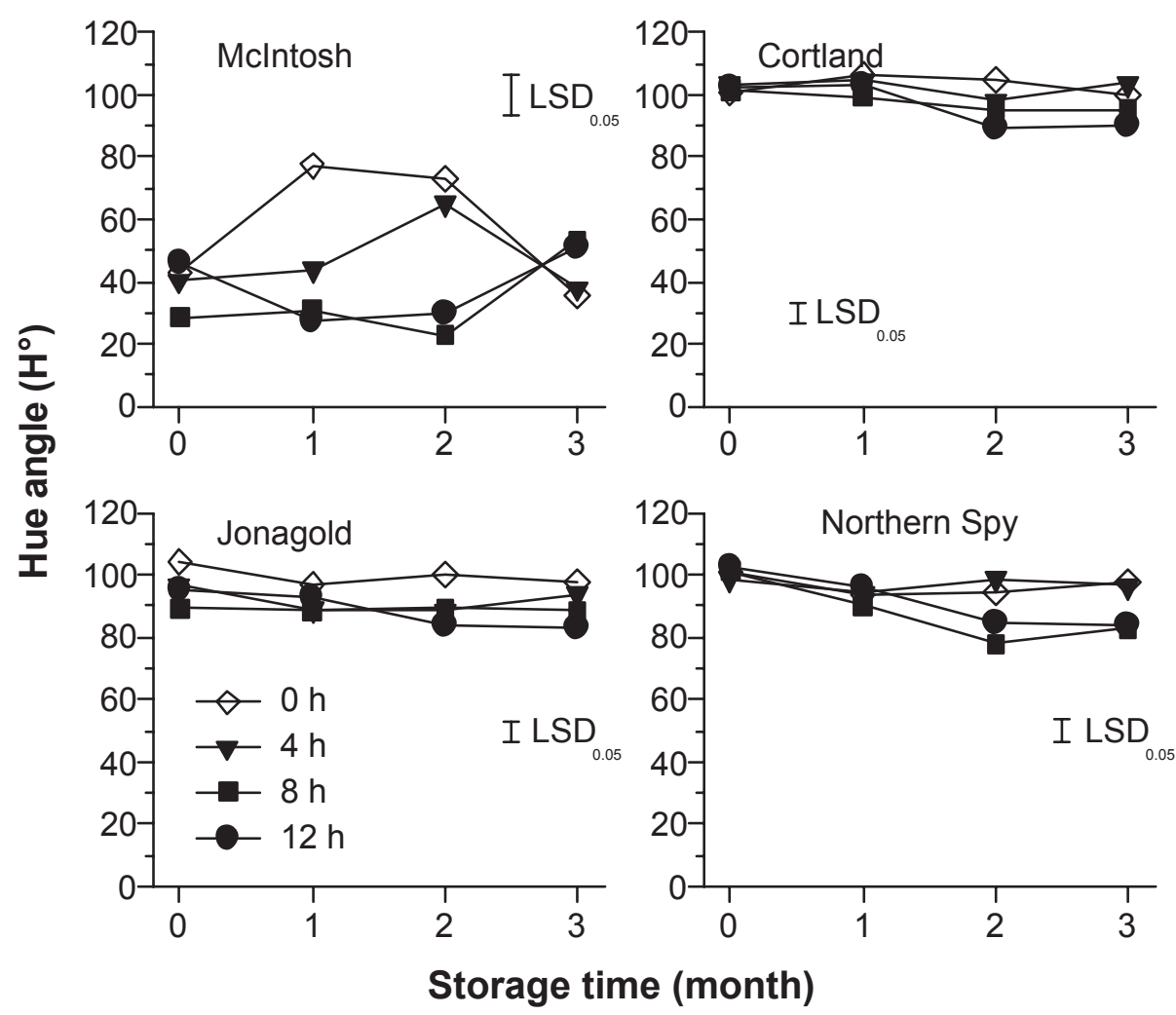

Fig. 7. The hue angle of the green side of 'McIntosh', 'Cortland', 'Jonagold', and 'Northern Spy' apples treated at $46{ }^{\circ} \mathrm{C}$ for $0,4,8$, or $12 \mathrm{~h}$ following $0,1,2$, or 3 months of storage at $0{ }^{\circ} \mathrm{C}$. The vertical bar represents the LSD at $P<0.05$ for comparison of means within the figure.

results in severe disruption or death of cells, ethylene evolution may decline. During heating, not only is endogenous ethylene production inhibited, but fruit may lose its response to exogenous ethylene (Yang et al., 1990). Among the four apple cultivars, 'Jonagold' was relatively resistant to heat stress. In the 4- and 8-h exposed 'Jonagold' apples, ethylene production consistently increased with storage duration, which suggests that 4- or 8-h heat exposure did not severely disrupt the fruit cells. The low levels of ethylene in the 'Jonagold' control compared with the other cultivars indicated that it may have been less mature, which may have affected its response to the heat treatments. Therefore, in addition to cultivar differences, maturity may affect the fruit's resistance to heat stress. The effect of fruit maturity on heat tolerance should be evaluated in order to aid in the interpretation of heat-stress-induced physiological responses. The variable rate of ethylene production by ripening fruit, which varies with age of the tissue and with environmental conditions, limits the usefulness of stress ethylene as a diagnostic tool.

Chlorophyll fluorescence has been used as a measurement of chloroplast function and the physiological status of whole plants and plant organs. During 3 months of storage at $0{ }^{\circ} \mathrm{C}$, $\mathrm{CF}$, measured as $\mathrm{Fv} / \mathrm{Fm}$, declined gradually in fruit of all four cultivars exposed to $46^{\circ} \mathrm{C}$ for 0 or $4 \mathrm{~h}$. During the 3 months of storage, however, $\mathrm{Fv} / \mathrm{Fm}$ was significantly lower in the 8- and 12-h exposed apples than in the controls and did not recover to the control value, indicating that the apple fruit were damaged irreversibly. Woolf and Laing (1996) also observed a similar drop in $\mathrm{Fv} / \mathrm{Fm}$ in avocado fruit injured by heat. Fluorescence is induced by direct excitation of the chlorophyll molecules of photosystem II (PSII) by light and their immediate relaxation. When PSII is functioning poorly, fluorescence characteristics are altered. Stresses such as high temperature reduce PSII function (Havaux et al., 1991). There is considerable evidence that the photosynthetic apparatus is an initial site of damage induced by heat stress (Ho, 1987). When apple fruit are stressed by heat, chloroplast integrity declines resulting in a decline in $\mathrm{Fv} / \mathrm{Fm}$. In other studies $\mathrm{CF}$ has been proposed as an indicator of physiological stress in apples resulting from low $\mathrm{O}_{2}$, high $\mathrm{CO}_{2}$, freezing, and heat (DeEll et al., 1995; Forney et al., 2000; Song et al., 2001).

While injury was not visible in most fruit $1 \mathrm{~d}$ after treatment, injured fruit could be identified by both elevated ethanol and reduced CF. Headspace ethanol concentration in control fruit $1 \mathrm{~d}$ after heat treatments was $<20 \mu \mathrm{mol} \cdot \mathrm{m}^{-3}$ for all four cultivars and these fruit developed no flesh browning during storage. Fruit with ethanol concentrations $>20 \mu \mathrm{mol} \cdot \mathrm{m}^{-3}$ posed a risk to develop flesh browning and this risk increased as the ethanol concentration increased. To identify fruit that would develop severe flesh browning during storage, a headspace ethanol concentration $>200 \mu \mathrm{mol} \cdot \mathrm{m}^{-3} 1 \mathrm{~d}$ after heat treatments was a useful predictive value. This value was effective in predicting the development of browning with only two exceptions. 'Jonagold' fruit treated at $46^{\circ} \mathrm{C}$ for $12 \mathrm{~h}$ had headspace ethanol concentrations of $\approx 100 \mu \mathrm{mol} \cdot \mathrm{m}^{-3}$ and developed significant flesh browning (rating $\approx 3$ ) after 3 months of storage and 'Northern Spy' fruit treated at $46^{\circ} \mathrm{C}$ for $4 \mathrm{~h}$ had similar ethanol headspace concentrations of $\approx 100 \mu \mathrm{mol} \cdot \mathrm{m}^{-3}$ and developed slight tissue browning (rating $<1$ ).

For CF, Fv/Fm values for control fruit $1 \mathrm{~d}$ after heat treatments ranged from 0.64 to 0.78 for the four cultivars tested. Heat-treated fruit having $\mathrm{Fv} / \mathrm{Fm}$ values of $<0.61 \mathrm{~d}$ after heat treatment all developed flesh browning. The only exception to this was 'Northern Spy' fruit that were treated at $46{ }^{\circ} \mathrm{C}$ for $4 \mathrm{~h}$, which developed slight flesh browning. For most fruit, threshold values of ethanol and $\mathrm{Fv} / \mathrm{Fm}$ were good predictors of peel and flesh browning that occurred in storage. Using a combination of these two measures may help to reduce errors in prediction. Ethanol concentrations and $\mathrm{Fv} / \mathrm{Fm}$ values were also stable during $7 \mathrm{~d}$ following heat stress when fruit were held at $20^{\circ} \mathrm{C}$ (Song et al., 2001).

It is concluded that both ethanol and $\mathrm{CF}(\mathrm{Fv} / \mathrm{Fm})$ are potential nondestructive indicators of physiological damage caused by heat stress and could be used to predict the risk of flesh browning during storage or marketing. Headspace ethanol is relatively easy to measure and fluorescence measurements are rapid $(0.3$ to $0.8 \mathrm{~s}$ ) and have potential for use as an in-line sorting tool. Following commercial heat treatments for quarantine or quality preservation, these indicators could be used to identify injured fruit so they can be removed prior to storage or marketing. To further develop these indicators as predictors of quality following storage, additional research is needed to determine seasonal, cultivar, and maturity effects. 


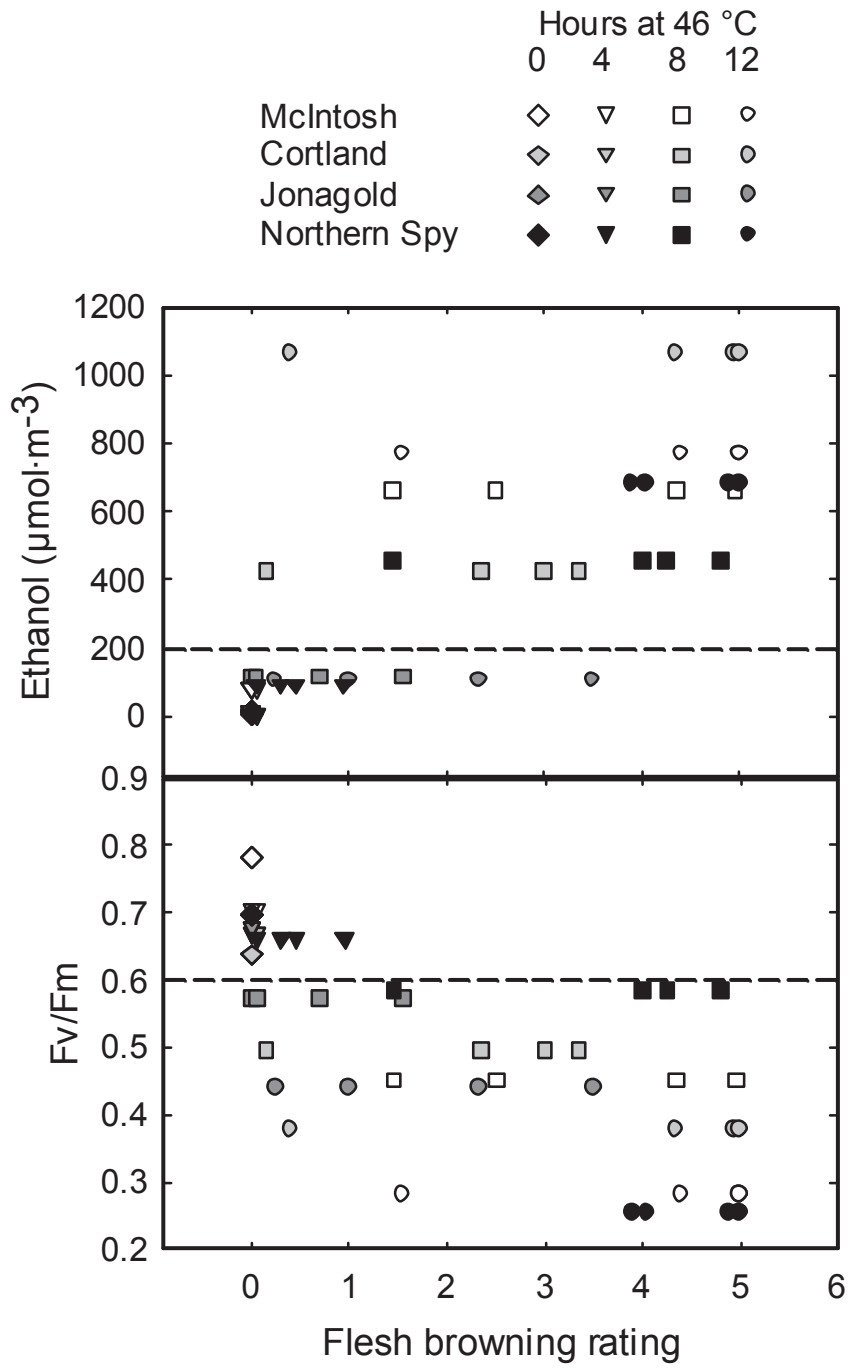

Fig. 8. Headspace ethanol concentrations and chlorophyll fluorescence (Fv/Fm) values of 'McIntosh', 'Cortland', 'Jonagold', and 'Northern Spy' apples 1 $\mathrm{d}$ after treatment at $46^{\circ} \mathrm{C}$ for $0,4,8$, or $12 \mathrm{~h}$ plotted against flesh browning ratings measured after $0,1,2$, or 3 months of storage at $0{ }^{\circ} \mathrm{C}$. The dashed lines represent proposed threshold values above (ethanol) or below (Fv/Fm) which flesh browning is likely to occur during storage.

\section{Literature Cited}

Bramlage, W.J., S.A. Weis, and M. Drake. 1985. Predicting the occurrence of poststorage disorders of 'McIntosh' apples from preharvest mineral analyses. J. Amer. Soc. Hort. Sci. 110:493-498.

Charron, C.S., D.J. Cantliffe, and R.R. Heath. 1995. Volatile emissions from plants. Hort. Rev. 17:43-72.

Davies, D.D. 1980. Anaerobic metabolism and the production of organic acids, p. 581-611. In: P.K. Stumpf and E.E. Conn (eds.). The biochemistry of plants, vol. 2. Academic, New York.

DeEll, J.R., R.K. Prange, and D.P. Murr. 1995. Chlorophyll fluorescence as an indicator of low $\mathrm{O}_{2}$ or high $\mathrm{CO}_{2}$ stress in apples during storage. HortScience 30:1058-1059.

Forney, C.F. and M.A. Jordan. 1998. Induction of volatile compounds in broccoli by postharvest hot-water dips. J. Agr. Food Chem. 46:5295-5301.
Forney, C.F., M.A. Jordan, K.U.K.G. Nicholas, and J.R. DeEll. 2000. Volatile emissions and chlorophyll fluorescence as indicators of freezing injury in apples. HortScience 35:1283-1287.

Genstat 5 Committee. 1993. Genstat 5 release 3 reference manual. Clarendon Press, Oxford, U.K.

Hardenburg, R.E., A.E. Watada, and C.Y. Wang. 1986. The commercial storage of fruits, vegetables, and florist and nursery stocks. U.S. Dept. Agr., Agr. Hdbk. No. 66.

Havaux, M., H. Greppin, and R.J. Strasser. 1991. Functioning of photosystems I and II in pea leaves exposed to heat stress in the presence or absence of light. Planta 186:88-89.

Ho, T.D. 1987. Heat stress responses in plants, p. 85-89. In: D.W. Newman and K.G. Wilson (eds.). Models in plant biochemistry. CRC Press, Boca Raton, Fla.

Jacobi, K.K., L.S. Wong, and J.E. Giles. 1993. Lychee (Lichi chinensis Sonn.) fruit quality following vapour heat treatment and cool storage. Postharvest Biol. Technol. 3:111-119.

Kimmerer, T.W. and T.T. Kozlowski. 1982. Ethylene, ethane, acetaldehyde, and ethanol production by plants under stress. Plant Physiol. 69:840-847.

Klein, J.D. and S. Lurie. 1992. Prestorage heating of apple fruit for enhanced postharvest quality: Interaction of time and temperature. HortScience 27:326-328.

Lay-Yee, M. and K.J. Rose. 1994. Quality of 'Fantasia' nectarines following forced air heat treatments for insect disinfestation. HortScience 29:663-666.

Lurie, S. 1998. Postharvest heat treatments of horticultural crops. Hort. Rev. 22:91-121.

Meheriuk, M., R.K. Prange, P.D. Lidster, and S.W. Porritt. 1994. Postharvest disorders of apples and pears. Agr. Can. Publ. 1737/E.

Porritt, S.W. and P.D. Lidster. 1978. The effect of pre-storage heating on ripening and senescence of apples during cold storage. J. Amer. Soc. Hort. Sci. 103:584-587.

Prange, R.K., M. Meheriuk, E.C. Lougheed, and P.D. Lidster. 1993. Harvest and storage, p. 64-69. In: C.G. Embree (ed.). Producing apples in eastern and central Canada. Agr. Can. Publ. 1899/E.

Smillie, R.M. 1992. Calvin cycle activity in fruit and the effect of heat stress. Scientia Hort. 51:83-95.

Song, J., L. Fan, C.F. Forney, and M.A. Jordan. 2001. Using volatile emissions and chlorophyll fluorescence as indicators of heat injury in apples. J. Amer. Soc. Hort. Sci. 126:771-777.

Templeton, C.W.G. and S.J. Colombo. 1995. A portable system to quantify seedling damage using stress-induced volatile emissions. Can. J. For. Res. 25:682-686.

Thomas, M. 1931. The production of ethyl alcohol and acetaldehyde by fruits in relation to the injuries occurring in storage. Ann. Appl. Biol. 18:60-73.

Tingey, D.T., C. Standley, and R.W. Field. 1976. Stress ethylene evolution: a measure of ozone effects on plants. Atmosphere Environ. 10:969-974.

Toivonen, P.M.A. 1997. Non-ethylene, non-respiratory volatiles in harvested fruits and vegetables: their occurrence, biological activity and control. Postharvest Biol. Technol. 12:109-125.

Woodstock, L.W. and R.B. Taylorson. 1981. Ethanol and acetaldehyde in imbibing soybean seeds in relation to deterioration. Plant Physiol. 67:424-428.

Woolf, A.B. and W.A. Laing. 1996. Avocado fruit skin fluorescence following hot water treatments and pretreatments. J. Amer. Soc. Hort. Sci. 121:147-151.

Yang, R.F., T.S. Cheng, and R.L. Shewfelt. 1990. The effect of high temperature and ethylene treatment on the ripening of tomatoes. J. Plant Physiol. 136:368-372. 